\title{
PREPARATION OF TWO NEW AMINOGLYCOSIDE ANTIBIOTICS
}

Sir :

A remarkable feature of the antibiotic neomycin ${ }^{1)}$ is the retention of considerable antibiotic activity by neamine (I, Fig. 1), a portion amounting to approximately onehalf of the neomycin molecule. Indeed, the original name for neamine was neomycin A and, when first isolated, it was regarded as a component of the antibiotic complex ${ }^{2}$. Although the activity of neamine is always less than that of neomycin B it approximates that of neomycin $C$ against many test organisms ${ }^{3)}$.

Fig. 1. Antibiotics and derivatives described.

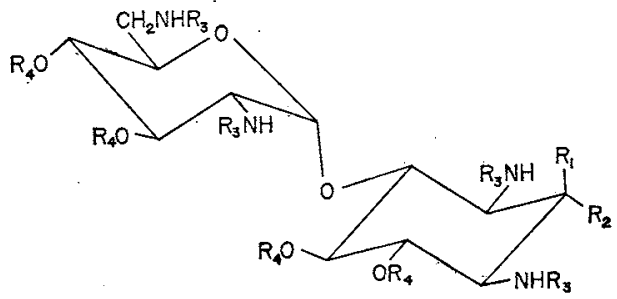

I (Neamine): $R_{1}=H$

II (Hybrimycin A 3): H

III (Hybrimycin B3): $\mathrm{OH}$

$\begin{array}{cc}\text { IV }: & \mathrm{H} \\ \mathrm{V}: & \mathrm{H}\end{array}$

VI: $\quad \mathrm{OH}$

VII: $\quad \mathrm{H}$

VIII: $\quad \mathrm{H}$

IX: $\quad \mathrm{OSi}\left(\mathrm{CH}_{3}\right)_{3}$

$\mathrm{R}_{2}=\mathrm{H}$
$\mathrm{OH}$
$\mathrm{H}$
$\mathrm{H}$
$\mathrm{OH}$
$\mathrm{H}$
$\mathrm{H}$
$\mathrm{OSi}\left(\mathrm{CH}_{3}\right)_{3}$
$\mathrm{H}$

We recently reported the isolation of a mutant of Streptomyces fradiae incapable of synthesizing neomycin ${ }^{4}$ in the absence of added 2-deoxystreptamine (1,3-diamino1,2,3-trideoxy-scyllo-inositol), the aminocyclitol subunit of the antibiotic. This mutant was also show $n^{4)}$ to convert two other aminocyclitols, streptamine (1,3-diamino-1, 3-dideoxy-scyllo-inositol, a portion of streptomycin) and 2-epistreptamine (1,3-diamino1,3-dideoxy-myo-inositol, part of the antibiotic spectinomycin) into four new antibiotics: hybrimycins $\mathrm{A} 1$ and $\mathrm{A} 2$ from streptamine and hybrimycins B1 and B2 from 2-epistreptamine.

In view of the antibiotic activity of neamine noted above it was deemed of interest to ascertain the activity of those portions of the hybrimycins (Fig. 1) corresponding to the neamine portion of neomycin. We now report the selective hydrolysis of hybrimycins $\mathrm{A}$ and $\mathrm{B}$ to yield these two new antibiotics, for which we propose the names hybrimycins A3 (II) and B3 (III), respectively.

Hybrimycin A and B complexes were hydrolyzed separately in $0.5 \mathrm{~N} \mathrm{HCl}$ for 5 hours at $85^{\circ} \mathrm{C}$, the mixtures were evaporated to dryness, and hybrimycins A3 and B3, respectively, were isolated from the residues by preparative paper chromatography in the solvent system methanol-concentrated ammonium hydroxide $(4: 1)$.

The structures of the new antibiotics were established by methods employed earlier ${ }^{4)}$. Comparison of the mass spectra of tetra-N-acetyltetra-O - trimethylsilylhybrimycins A3 (VIII) and B3 (IX) with that of the corresponding derivative of neamine $(\mathrm{VII})^{4,5)}$ showed that numerous peaks including the molecular ion $\mathrm{M}$ (m/e 866 vs 788$)$ were shifted $88 \mathrm{~m}$. u. higher, corresponding to an additional trimethylsilyloxy group. Since the peak corresponding to the aminocyclitol moiety (a) was shifted (m/e 461 os 373) while that arising from the aminosugar moiety $(\mathrm{b}, \mathrm{m} / \mathrm{e}$ 389) was not, the additional functional group must be located on the aminocyclitol moiety

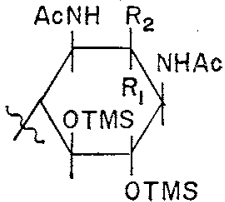

a

$\mathrm{m} / \mathrm{e} 46 \mathrm{I}\left(\mathrm{R}_{1}\right.$ or $\mathrm{R}_{2}=$ OTMS) $\mathrm{m} / \mathrm{e} 373\left(\mathrm{R}_{1}=\mathrm{R}_{2}=\mathrm{H}\right)$

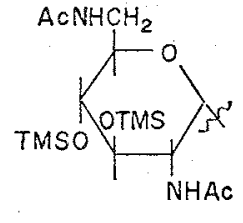

b

$\mathrm{m} / \mathrm{e} 389$ 
Table 1. Properties of $\mathrm{N}$-acetyl derivatives

\begin{tabular}{l|c|c}
\hline $\begin{array}{c}\text { Antibiotic } \\
\text { derivatized }\end{array}$ & {$[\alpha]_{\mathrm{D}}^{22}\left(c 0.01\right.$, in $\left.\mathrm{H}_{2} \mathrm{O}\right)$} & $\mathrm{Rf} *$ \\
\hline Neamine & $76.2^{\circ}$ & 0.32 \\
Hybrimycin A3 & $65.2^{\circ}$ & 0.23 \\
Hybrimycin B3 & $83.5^{\circ}$ & 0.27 \\
\hline
\end{tabular}

* Rf values for paper chromatography in 1-butano1pyridine - water $(6: 4: 3)$.

Table 2. Antibacterial activity of hybrimycins A 3 and $B 3$.

\begin{tabular}{|c|c|c|c|}
\hline \multirow[b]{2}{*}{ Test organism* } & \multicolumn{3}{|c|}{$\operatorname{MIC}(\mu \mathrm{g} / \mathrm{ml})^{* *}$} \\
\hline & $\begin{array}{l}\text { Nea- } \\
\text { mine }\end{array}$ & $\begin{array}{l}\text { Hybri- } \\
\text { mycin } \\
\text { A3 }\end{array}$ & $\begin{array}{l}\text { Hybri- } \\
\text { mycin } \\
\text { B3 }\end{array}$ \\
\hline $\begin{array}{c}\text { Staphylococcus aureus } \\
\text { OSU } 284\end{array}$ & 6.4 & 50 & 200 \\
\hline $\begin{array}{l}\text { Staphylococcus aureus } \\
\text { ATCC 151 }\end{array}$ & 3.2 & 50 & 200 \\
\hline $\begin{array}{l}\text { Staphylococcus } \\
\text { hemolyticus UC } 152\end{array}$ & 25.0 & 100 & 200 \\
\hline $\begin{array}{l}\text { Escherichia coli } \\
\text { ATCC 26 }\end{array}$ & 50 & 200 & $>200$ \\
\hline $\begin{array}{r}\text { Klebsiella pneumoniae } \\
\text { ATCC } 10031\end{array}$ & 6.4 & 100 & $>200$ \\
\hline $\begin{array}{cc}\text { Salmonella } & \text { schottmuel- } \\
\text { leri } & \text { ATCC } 9149\end{array}$ & 50 & 200 & $>200$ \\
\hline $\begin{array}{l}\text { Bacillus subtilus } \\
\text { UC } 564\end{array}$ & 3.0 & 25 & 50 \\
\hline
\end{tabular}

* OSU, Ohio State University ; UC, The Upjohn Co. ; ATCC, American Type Culture Collection.

* The antibiotic preparations were dissolved in brain-heart infusion broth and twofold decrements were made from $200 \mu \mathrm{g} / \mathrm{ml}$. An 18-hour culture of each test organism was diluted $1: 2000$ and 1 drop of the diluted suspension was added to $1 \mathrm{ml}$ of broth with the antibiotic. The test system was estimated to contain 105 organisms per ml. All tubes were incubated at $37^{\circ} \mathrm{C}$ for 24 hours. The minimum inhibitory concentration (MIC) is the lowest concentration of antibiotic which prevented growth.

of hybrimycins A3 and B3. The nmr spectra of hybrimycins $\mathrm{A} 3$ and $\mathrm{B} 3$ show no absorption by methylene protons $\left(\mathrm{ABX}_{2}\right.$ multiplet near $\delta 2.0$ ), characteristic of deoxystreptamine derivatives ${ }^{6}$, conclusively locating the additional hydroxyl group on the carbon between the amino groups of the aminocyclitol moiety. The ORD plain curves in the region 240 to $600 \mathrm{~m} \mu$, as well as the specific rotation (see Table 1 ), for tetra-N-acetylneamine (IV) lie approximately equidistant between those for tetra-Nacetylhybrimycins $A 3(\mathrm{~V})$ and $\mathrm{B} 3(\mathrm{VI})$, in accord with the expected rotatory effects of opposite absolute configurations at $\mathrm{C}-2$ of the aminocyclitol moiety. The greater mobility of tetra-N-acetylhybrimycin $\mathrm{B} 3$ vs tetra-N-acetylhybrimycin $\mathrm{A} 3$ in paper chromatography is consistent with an axial hydroxyl group in the former and an equatorial hydroxyl in the latter ${ }^{7}$. Thus, the hybrimycin A3 and B3 structures are established as in Fig. 1.

The antibacterial properties of hybrimycins A 3 and $B 3$ are compared with those of neamine in Table 2. Hybrimycin A3 is somewhat less active than neamine and hybrimycin B3 is less active still. The relative activities mirror those of hybrimycins $A$ ( $A 1$ plus $A 2)$ and $B(B 1$ plus $B 2$ ) vs neomycin (B plus $\mathrm{C})^{4)}$. These data indicate that the methylene group in the deoxystreptamine moiety of neamine is not essential for its antibacterial activity, and that the stereochemistry of substitution by a hydroxyl group has an influence on the antibacterial activity of the modified antibiotic. These conclusions are essentially in agreement with the structure-activity relationships drawn by Masukawa and Tanaka ${ }^{8)}$ from the codon misreading activity of other aminoglycoside antibiotics.

\section{Acknowledgement}

This work was supported in part by Grants (Nos. AI-01278 and AI-04769) from the National Institute of Allergy and Infectious Diseases, U.S. Public Health Service. The authors thank Dr. W. T. Sokоцski, the Upjohn Co., Kalamazoo, Michigan, for determining the MIC data reported and $\mathrm{Mr}$. J. WRONA, University of Illinois, for obtaining the mass spectra.

\section{W. Thomas ShIER \\ Kenneth L. Rinehart, Jr. \\ Department of Chemistry \\ David Gottiem \\ Department of Plant Pathology \\ University of Illinois \\ Urbana, Illinois 61801, U.S.A.}

(Received November 24, 1969)

\section{References}

1) Rinehart, K. L., Jr.: The neomycins and related antibiotics. John Wiley \& Sons, Inc., New York, 1964 
2) a) PeCK, R. L.; C.E. Hoffhine, Jr., P. GALE \& K. FOLKERS: Streptomyces antibiotics. XXIII. Isolation of neomycin A. J. Am. Chem. Soc. $71: 2590 \sim 2591,1949$ b) Swart, E. A.; H. A. Lechevaliger \& S. A. WAKSMAN: The identity of the neomycin complex, as measured by countercurrent distribution and microbiological analyses. J. Am. Chem. Soc. 73: 3253 3258, 1951

3) Sebex, O. K.: Correlation between the structure of neomycin $\mathrm{B}$ and its action on bacteria. J. Bact. $75: 199 \sim 204,1958$

4) Shier, W. T.; K. L. Rinehart, Jr. \& D. GotTLIEB: Preparation of four new antibiotics from a mutant of Streptomyces fradiae. Proc. Nat. Acad. Sci. U.S. 63 :
$198 \sim 204,1969$

5) DeJongh, D. C.; J. D. Hribar, S. Hanessian \& P.W.K. Woo: Mass spectrometric studies on aminocyclital antibiotics. J. Am. Chem. Soc. $89:$ 3364 3365, 1967

6) Lemieux, R. U. \& R. J. Cushley: The configuration of deoxystreptamine. Canad. J. Chem. $41: 858 \sim 862,1963$

7) Isherwood, F.A. \& M.A. Jermyn: Relationship between the structure of the simple sugars and their behavior on the paper chromatogram. Biochem. J. $48: 515 \sim 524$, 1951

8) Masukawa, H. \& N. Tanaka: Miscoding: activity of aminosugars. J. Antibiotics 21 : $70 \sim 72,1968$ 